\title{
Kemampuan Auditor Terhadap Kualitas Audit Inspektorat Provinsi Riau
}

\author{
IKA BERTY APRILIYANI \\ Fakultas Ekonimi Universitas Lancang Kuning Pekanbaru \\ Jalan Yos Sudarso KM 8 Rumbai \\ Telp. (0761) 52581 email ; bertyrazali@yahoo.com
}

\begin{abstract}
This study aims to determine the effect of competence and due professional care on the quality of the audit results Internal Auditor at Inspectorate Riau Province (APIP). This study uses multiple regression analysis. The population in the study were all auditors in Riau Provincial Inspectorate totaling 52 people. The population is all auditors in Riau Province Inspectorate which totaled 52 people. While the number of samples using a sampling technique saturated / census sampling technique in which all members of the population used as a sample. The results showed that the statistically variable competence and due professional care have a significant effect on audit quality. The implications of this study emphasize the importance of the ability of auditors in each audit assignment.
\end{abstract}

Keywords: Audit Quality, Competence, Due Professional Care

Auditor dalam melakukan pekerjaannya dituntut untuk menghasilkan laporan audit yang berkualitas. Untuk menghasilkan sesuatu yang berkualitas tentu dipengaruhi oleh banyak faktor, tidak terkecuali dengan hasil audit. Kemampuan auditor dalam melakukan pekerjaannya merupakan salah satu faktor yang dapat menghasilkan audit yang berkualitas. Hasil audit yang berkualitas merupakan hal yang harus dicapai oleh para auditor dalam setiap proses audit. Hasil audit yang berkualitas sangat diperlukan oleh pihak-pihak yang berkepentingan karena hasil tersebut harus dapat diandalkan oleh pengguna sebagai dasar dalam pengambilan keputusan (Arens, 2006 ; 25 dalam Apriliyani et al., 2013).

Kualitas audit merupakan probabilitas seorang auditor dapat menemukan dan melaporkan penyelewengan dalam sistem akuntansi klien (DeAngelo,1981). Didasarkan pada definisi tersebut tercermin bahwa temuan audit dapat menunjukkan tingkat kemampuan auditor dalam mendeteksi kesalahan pada laporan keuangan. Sehingga semakin banyak temuan semakin berkualitas audit yang telah dilaksanakan (DeAngelo,1981).
Banyak faktor-faktor yang dapat mempengaruhi kualitas audit auditor. Faktorfaktor tersebut diantaranya adalah; Independensi (Wilcox,1952 di dalam Taufiq, 2010), kompetensi auditor, respon terhadap klien, kecermatan dan keseksamaan profesional (due profesional care), pemahaman sistem akuntansi klien, pemahaman terhadap sistem pengendalian intern serta sikap skeptisme auditor (Samelson et al., 2006), dan Lingkungan pengendalian (control environment) (Murtanto, 2005;30).

Kompetensi berhubungan dengan keahlian, pengetahuan, dan pengalaman sehingga auditor yang kompeten adalah auditor yang memiliki pengetahuan, pelatihan, keterampilan, dan pengalaman yang memadai agar bisa berhasil menyelesaikan pekerjaan auditnya (Lee, 1993:80). Tugas pengauditan adalah tugas untuk memverifikasi dan mengatestasi kualitas informasi akuntansi yang kompleks dan teknis yang terdapat di dalam informasi keuangan yang dilaporkan kepada pemegang saham (Lee, 1993: 82). Oleh karena itu, relevan jika diasumsikan bahwa auditor harus memiliki keahlian dan pengalaman yang memadai dan pantas untuk mencapai tujuan 
dari fungsi audit. Jika karakteristik personal ini kurang atau tidak memadai, maka bisa diduga bahwa auditor akan sukar mencapai tujuan auditnya.

Due professional care memiliki arti kemahiran professional yang cermat dan seksama (PSA No.4 SPAP 2001). Penggunaan kemahiran profesional dengan cermat dan seksama menyangkut apa yang dikerjakan auditor dan bagaimana kesempurnaan pekerjaannya tersebut (SPAP, 2001). Penerapan kecermatan dan keseksamaan diwujudkan dengan dilakukannya revieu secara kritis pada setiap tingkat supervise terhadap pelaksanaan audit. Kecermatan dan keseksamaan menyangkut apa yang dikerjakan auditor dilakukan pada berbagai aspek audit dan kesempurnaan pekerjaan, seperti evaluasi risiko audit, penentuan signifikan tidaknya risiko yang diidentifikasi dalam audit dan dampaknya, evaluasi bukti audit, pemilihan pengujian dan hasilnya, penentuan kompetensi, integritas dan kesimpulan yang diambil pihak lain yang berkaitan dengan penugasan audit.
Dalam
konteks
Inspektorat

Provinsi/Kabupaten/Kota sebagai Aparat Pengawas Internal Pemerintah (APIP) yang melaksanakan audit internal dilingkungan pemerintah daerah, kriteria kualitas yang dikemukakan oleh DeAngelo yaitu probabilitas temuan dan pelaporan atas penyelewengan, dapat juga merupakan kriteria audit yang berkulitas bagi Inspektorat Provinsi/Kabupaten/Kota sebagai Aparat Pengawas Internal Pemerintah (APIP).

Berkaitan dengan kualitas audit, auditor inspektorat dalam melaksanakan audit juga dipengaruhi berbagai faktor seperti independensi, kompetensi, kecermatan dan keseksamaan, serta lingkungan pengendalian (Apriliyani et al., 2013). Hal ini tercantum dalam standar audit Aparat Pengawas Internal Pemerintah (APIP). Standar merupakan suatu persyaratan umum yang harus dimiliki oleh auditor internal pemerintah dalam hal ini Aparat Pengawas Internal Pemerintah (APIP) yang dilaksanakan oleh Inspektorat Provinsi/ Kabupaten/Kota. Dalam Standar umum pertama APIP disebutkan bahwa audit harus dilaksanakan oleh seseorang atau lebih yang memiliki keahlian dan pelatihan teknis yang cukup sebagai auditor (Permenpan No.PER/05/M.PAN/03/2008). Auditor harus memiliki dan meningkatkan pengetahuan mengenai metode dan teknik audit serta segala hal yang menyangkut pemerintahan seperti organisasi, fungsi, program, dan kegiatan pemerintah (BPKP,1998;32).

Banyak permasalahan hukum muncul belakangan ini terutama masalah korupsi, kolusi dan nepotisme (KKN) terjadi pada organisasi pemerintah dengan modus penyuapan, pungutan liar serta penggunaan aset negara untuk kepentingan pribadi. Inspektorat sebagai auditor internal pemerintah diharapkan dapat memberikan kontribusi penting dalam fungsinya sebagai pemeriksa, dengan melaksanakan setiap rencana audit dengan sikap profesional, dan dapat memberikan informasi berupa temuan-temuan audit yang dapat dipercaya sebagai cerminan kualitas auditnya.

Audit yang berkualitas akan memberikan informasi yang memadai kepada organisasi pemerintah yang diperiksa tentang kelemahan pengendalian internal, kecurangan dan penyimpangan peraturan perundang-undangan (Standar Pemeriksaan Keuangan Negara 2007) yang terjadi dalam organisasi. Untuk menghasilkan audit yang berkualitas tinggi, penelitian terdahulu telah menemukan bahwa terdapat faktor-faktor seperti kompetensi dan due professional care auditor yang berperan menentukan kualitas audit (Andy 2010, Icuk

2010, Apriliyani et al., 2013).

Penelitian mengenai faktor-faktor yang mempengaruhi kualitas audit telah dilakukan sebelumnya oleh Andy (2010), menguji pengaruh kompetensi dan indepensi auditor terhadap kualitas audit yang dihasilkan. Hasil penelitian yang dilakukan menunjukkan bahwa kompetensi auditor berpengaruh terhadap kualitas audit yang dilakukan, sedangkan untuk variabel indepedensi tidak berpengaruh terhadap kualitas audit. Namun Penelitian Icuk (2010), meneliti Faktor-faktor independensi, 
pengalaman, due professional care dan akuntabilitas terhadap kualitas audit. Hasil penelitian menunjukkan bahwa indepedensi, due professional care dan akuntabilitas berpengaruh signifikan terhadap kualitas audit, sedangkan faktor pengalaman tidak berpengaruh terhadap kualitas audit.

Penelitian yang dilakukan oleh Samelson et al. (2006) membuktikan bahwa kompetensi auditor, respon terhadap klien, kecermatan dan keseksamaan profesional, pemahaman sistem akuntansi klien, pemahaman terhadap sistem pengendalian intern serta sikap skeptisme auditor mempunyai hubungan siginfikan dengan kualitas audit yang dipersepsikan auditee. Berikutnya penelitian yang dilakukan Apriliyani et al. (2013), menguji faktor Independensi, kompetensi, due profesional care, dan lingkungan pengendalian, penelitian menghasilkan terdapat pengaruh Independensi, kompetensi, dan due profesional care terhadap kualitas audit, sedangkan lingkungan pengendalian tidak berpengaruh.

Melihat hasil-hasil penelitian terdahulu, penulis tertarik untuk meneliti faktor yang ada pada diri auditor yakni kemampuan auditor berupa kompetensi dan due profesional care terhadap kualitas hasil audit. Penelitian ini mencoba menguji kembali penelitian Icuk (2010) mengenai pengaruh kompetensi auditor, dan independensi auditor terhadap kualitas audit. Penelitian ini berbeda dengan penelitian sebelumnya yang melakukan penelitian pada Kantor Akuntan Publik, selain obyek penelitan yang berbeda yaitu auditor Inspektorat Daerah di Provinsi Riau, penelitian ini juga menambahkan variabel due professional care (kecermatan dan kesesksamaan profesi auditor), dan lingkungan pengendalian sebagai variabel independen.

Menurut

mendefinisikan kualitas DeAngelo(1981), mendefinisikan kualitas audit sebagai probabilitas nilaian-pasar bahwa laporan keuangan mengandung kekeliruan material dan auditor akan menemukan dan melaporkan kekeliruan material tersebut atau dengan kata lain sebagai temuan audit. Temuan audit adalah total jumlah kasus temuan oleh Inspektorat yang terdiri dari: (1) kerugian daerah; (2) potensi kerugian daerah; (3) kekurangan penerimaan; (4) administrasi; (5) ketidakhematan; (6) ketidakefisienan; dan (7) ketidakefektifan.

Lee, et al (1999) mengemukakan kualitas audit menurut mereka adalah probabilitas bahwa auditor tidak akan melaporkan laporan audit dengan opini wajar tanpa pengecualian untuk laporan keuangan yang mengandung kekeliruan material. Definisi ketiga adalah definisi yang diberikan oleh Titman, et al (1986) menurut mereka, kualitas audit diukur dari akurasi informasi yang dilaporkan oleh auditor. Terakhir, kualitas audit ditentukan dari kemampuan audit untuk mengurangi noise dan bias dan meningkatkan kemurnian (fineness) pada data akuntansi (Wallace, 1980 di dalam Watkins et al., 2004).

DeAngelo (1981) setuju dengan pendapat bahwa kualitas audit harus dilihat dari dua sisi: permintaan atau input atau berhubungan dengan pihak klien dan pasokan atau output atau berhubungan dengan pihak auditor. Namun, di dalam analisisnya, ia mengabaikan, untuk tujuan penyederhanaan analisis, sisi permintaan atau input. Dengan demikian, output dari audit adalah sebuah verifikasi independen terhadap data keuangan yang disusun oleh manajemen yang dilengkapi dengan opini sesuai dengan dimensi kualitas. Karena auditor bertugas untuk memverifikasi data keuangan yang disusun oleh manajemen, maka kualitas audit definisikan "the marketassessed joint probability that a given auditor will both (a) discover a breach in the client'saccounting system, and (b) report the breach" (DeAngelo, 1981).

Poin-poin penting dari pengertian di atas adalah bahwa audit yang berkualitas adalah audit yang dilaksanakan oleh orang yang kompeten dan orang yang independen. Auditor yang kompeten adalah auditor yang memiliki kemampuan teknologi, memahami dan melaksanakan prosedur audit yang benar, memahami dan menggunakan 
metode penyampaian yang benar, dll. Sebaliknya, auditor yang independen adalah auditor yang jika menemukan pelanggaran, akan secara independen melaporkan pelanggaran tersebut. Probabilitas auditor akan melaporkan adanya pelanggaran atau independensi auditor tergantung pada tingkat kompetensi mereka. DeAngelo (1981) berpendapat bahwa kedua kualitas itu hanya dimiliki oleh kantor akuntan yang berukuran besar (Big 8 pada zaman itu). Pendapat ini didukung oleh Lee (1993). Menurut Lee, jika auditor dengan klien sama-sama memiliki ukuran yang relatif kecil, maka ada probabilitas yang besar bahwa penghasilan auditor akan menjadi tergantung pada fee audit yang dibayarkan oleh kliennya. Oleh karena itu, auditor kecil ini akan cenderung tidak independen terhadap kliennya. Sebaliknya, di ekstrem yang lain, jika auditor berukuran besar, maka ia cenderung akan lebih independen terhadap kliennya, baik ketika kliennya berukuran besar maupun kecil. Oleh karena itu, ukuran kantor akuntan inikemudian secara luas diterima oleh peneliti akuntansi dan digunakan secara luas sebagai ukuran kualitas audit.

Suatu hal yang tidak dapat disangkal lagi bahwa kualitas produk adalah kunci keberhasilan suatu organisasi yang sangat penting. Kemampuan suatu organisasi menghasilkan produk barang maupun jasa yang bermutu tinggi merupakan kunci sukses bagi keberhasilan masa mendatang, Tatang (1995;21). Selanjutnya untuk menentukan faktor-faktor penentu kualitas jasa audit Carcello (2004), melakukan survey terhadap pembuat laporan keuangan, pengguna dan auditornya. Carcello (1992) meringkas 41 atribut kualitas audit menjadi hanya 11 faktor penentu kualitas audit dan juga digunakan Behn et al., (1997) untuk menghubungkan kualitas audit dengan kepuasan klien/auditee, yaitu: 1) Pengalaman tim audit dan KAP dalam melakukan pemeriksaan laporan keuangan klien, 2) Responsif atas kebutuhan klien, 3) Kompetensi anggota-anggota tim audit terhadap prinsip-prinsip akuntansi dan norma-norma pemeriksaan, 4) Sikap independensi dalam segala hal dari individu-individu tim audit dan KAP, 5) Anggota tim audit sebagai suatu kelompok yang bersifat hati-hati, 6) KAP memiliki komitmen yang kuat terhadap kualitas, 7) Keterlibatan pimpinan KAP dalam pelaksanaan audit, 8) Pelaksanaan audit lapangan, 9) Keterlibatan komite audit sebelum, pada saat, dan sesudah audit, 10) Standar-standar etika yang tinggi dari anggota anggota tim audit, 11) Menjaga sikap skeptis dari anggota-anggota tim audit, 12) Kecermatan dan keseksamaan auditor.

Dalam penelitian ini, penulis akan lebih memfokuskan kepada dus faktor yang mepengaruhi kualitas audit, yaitu faktor kompetensi Auditor, dan due professional care (kecermatan dan keseksamaan profesi auditor). Kompetensi berhubungan dengan keahlian, pengetahuan, dan pengalaman sehingga auditor yang kompeten adalah auditor yang memiliki pengetahuan, pelatihan, keterampilan, dan pengalaman yang memadai agar bisa berhasil menyelesaikan pekerjaan auditnya (Lee, 1993:80). Pada masa lalu seorang auditor yang kompeten adalah auditor yang menguasai teknik pembukuan saja. Namun, Lee (1993: 66) berpendapat bahwa auditor saat ini diharapkan untuk memiliki kompetensi profesional yang substansial di berbagai area yang saling berkaitan yang berpengaruh terhadap tugas auditnya. Di antara keahlian yang harus dikuasai oleh auditor adalah akuntansi, statistika, komputasi, ekonomika, hukum, manajemen, dan kebijakan publik. Oleh karena itu, kebutuhan kompetensi saat ini jelas berbeda dengan kompetensi pada masa lalu yang hanya bisa dibatasi pada kompetensi pembukuan.

Tugas pengauditan adalah tugas untuk memverifikasi dan mengatestasi kualitas informasi akuntansi yang kompleks dan teknis yang terdapat di dalam informasi keuangan yang dilaporkan kepada pemegang saham (Lee, 1993: 82). Oleh karena itu, relevan jika diasumsikan bahwa auditor harus memiliki keahlian dan pengalaman yang memadai dan pantas untuk mencapai tujuan 
dari fungsi audit. Jika karakteristik personal ini kurang atau tidak memadai, maka bisa diduga bahwa auditor akan sukar mencapai tujuan auditnya.

Pengauditan sendiri adalah sebuah penyerahan jasa. Dari pekerjaan itu yang terjadi adalah penyerahan barang nonfisik atau tidak berwujud dan hanya laporan audit dan fee audit yang memiliki wujud. Laporan audit tersebut juga yang dijadikan bukti tentang kecakapan, upaya, dan waktu yang didedikasikan untuk menghasilkan laporan dan menjustifikasi fee. Implisit dari fakta ini adalah bahwa tidak ada bukti berwujud bagi pemegang saham dan konstituen eksternal lain tentang aktivitas audit yang telah dilaksanakan hingga sebuah laporan audit selesai. Bahkan, laporan audit sendiri tidak bisa menggambarkan apakah aktivitas audit telah dilaksanakan dengan baik atau tidak. Oleh karena itu, para pengguna laporan sangat memerlukan seseorang yang memiliki keahlian profesional yang bisa dijadikan pegangan, yang memiliki kredibilitas karena kompetensinya. Jika hal itu tidak bisa dipenuhi, maka auditor tidak akan bisa memenuhi apa yang diekspektasi oleh pengguna laporan auditor (Lee, 1993: 82).

Jadi, bisa disimpulkan bahwa kompetensi dan independensi adalah sepasang kualitas yang harus dimiliki oleh auditor. Kompetensi berhubungan dengan independensi praktisi (Mautz dan Sharaf, 1961: 247). Seorang auditor yang memiliki pendidikan, keahlian, pelatihan, dan pengalaman yang memadai akan bisa merencanakan program audit, memverifikasi bukti, dan menyusun laporan secara independen. Artinya, auditor hanya akan bisa independen, jika ia memiliki keahlian yang memadai dalam melakukan pekerjaannya dan memberikan opininya. Sebaliknya, auditor yang tidak kompeten sulit untuk bisa menjadi independen karena ia tidak memiliki syarat utama untuk menjadi independen, yaitu kompetensi.

Due professional care memiliki arti kemahiran professional yang cermat dan seksama. Menurut PSA No. 4 SPAP (2001), kecermatan dan keseksamaan dalam penggunaan kemahiran profesional menuntut auditor untuk melaksanakan skeptisme profesional, yaitu suatu sikap auditor yang berpikir kritis terhadap bukti audit dengan selalu mempertanyakan dan melakukan evaluasi terhadap bukti audit tersebut. Penggunaan kemahiran profesional dengan cermat dan seksama memungkinkan auditor untuk memperoleh keyakinan memadai bahwa laporan keuangan bebas dari salah saji material, baik yang disebabkan oleh kekeliruan maupun kecurangan.

Auditor mempunyai kewajiban untuk melaksanakan jasa profesional dengan sebaik- baiknya sesuai dengan kemampuannya, demi kepentingan pengguna jasa dan konsisten dengan tanggung jawab profesi kepada publik (Mulyadi, 2002). Sikap kehati-hatian dalam profesi auditor diharuskan untuk merencanakan dan mengawasi secara seksama. Penggunaan kemahiran profesional dengan cermat dan seksama menuntut auditor untuk melaksanakan skeptisme profesional. Sikap skeptisme profesional merupakan sikap yang mencakup pikiran yang selalu mempertanyakan dan melakukan evaluasi secara kritis bukti audit.

Dalam Peraturan Badan Pemeriksa Keuangan Republik Indonesia No. 01 Tahun 2007 tentang Standar Pemeriksaan Keuangan dinyatakan dalam pelaksanaan pemeriksaan serta penyusunan laporan hasil pemeriksaan, pemeriksa wajib menggunakan kemahiran profesionalnya secara cermat dan seksama. Kemudian dalam standar audit aparat pengawas intern pemerintah dinyatakan bahwa Auditor harus menggunakan keahlian profesionalnya dengan cermat dan seksama (due professional care) dan secara hati-hati (prudent) dalam setiap penugasan. Due professional care dapat diterapkan dalam pertimbangan profesional (professional judgement), walaupun dalam prakteknya masih terjadi penarikan kesimpulan yang belum tepat saat proses audit telah dilakukan.

Dalam SPKN 2007 disebutkan bahwa kemahiran professional (due professional care) yaitu sikap yang mencakup pikiran 
yang selalu mempertanyakan dan melakukan evaluasi secara kritis terhadap bukti pemeriksaan. Auditor menggunakan pengetahuan, keahlian dan pengalaman yang dituntut oleh profesinya untuk melaksanakan pengumpulan bukti dan evaluasi obyektif mengenai kecukupan, kompetensi dan relevansi bukti. Karena bukti dikumpulkan dan dievaluasi selama pemeriksaan, skeptisme profesional harus digunakan selama pemeriksaan. Dalam menggunakan skeptisme profesional, pemeriksa tidak boleh puas dengan bukti yang kurang meyakinkan walaupun menurut anggapannya manajemen entitas yang diperiksa adalah jujur.

\section{METODE}

Metode yang digunakan dalam penelitian ini metode Survei, dengan kuisioner sebagai alat pengumpul data yang pokok (Singarimbun, 1998). Survei merupakan studi yang bersifat kuantitatif yang digunakan untuk meneliti gejala suatu kelompok atau perilaku individu. Peneliti menggunakan desain penelitian ini untuk mengetahui apakah kompetensi auditor dan due profesional care auditor berpengaruh terhadap kualitas audit APIP pada Inspektorat Provinsi Riau baik secara parsial maupun secara simultan. Populasi dalam penelitian ini adalah seluruh auditor/pemeriksa Inspektorat Provinsi Riau yang berdasarkan DUK Inspektorat Provinsi Riau berjumlah 52 (lima puluh dua) orang. Teknik pengambilan sampel pada penelitian ini adalah sampling jenuh/sensus yaitu teknik penentuan sampel dimana semua anggota populasi digunakan sebagai sampel (Sugiyono, 2001;58). Alasan menggunakan sampling jenuh/sensus karena jumlah populasi yang realtif kecil. Metode analisis data yang digunakan dalam penelitian ini adalah menggunakan analisis Regresi linear berganda, untuk mengetahui tingkat signifikansi masing-masing variabel independen.

\section{HASIL}

Hasil pengujian regresi linier berganda membentuk perumusan regresi sebagai berikut:

$$
Y=1,549+0.743 X 1+0,364 X 2+e
$$

Berdasarkan persamaan tersebut pengaruh setiap variabel independen terhadap variabel dependen tercermin dari koefisien regresi. Pengaruh kompetensi sebesar 74,3\% dan due professional care sebesar 36,4\%. Dari persamaan tersebut juga dapat diartikan bahwa setiap peningkatan kualitas audit sebesar 1 persen, maka akan meningkatkan (karena nilainya positif) kompetensi auditor sebesar 74,3\%, setiap peningkatan kualitas audit sebesar 1 persen maka akan meningkatkan due Professional care sebesar $36,4 \%$. Hasil penelitian menunjukkan bahwa Kompetensi Auditor, dan due professional care secara simultan dan berpengaruh secara parsial signifikan terhadap Kualitas Audit APIP pada Inspektorat Provinsi Riau.

\section{PEMBAHASAN}

Hasil penelitian menunjukkan bahwa Kompetensi Auditor berpengaruh terhadap Kualitas Audit. Hasil pengujian statistik pada uji t menunjukkan tingkat signifikan Kompetensi auditorsebesar 0,000 yang lebih kecil dari tingkat signifikan 0,05 sehingga hipotesis yang dibuat diterima. Hasil penelitian ini mendukung teori yang dikemukakan oleh Lee (1993) yang menyatakan bahwa tugas pengauditan adalah tugas untuk memverifikasi dan mengatestasi kualitas informasi akuntansi yang kompleks dan teknis yang terdapat di dalam informasi keuangan yang dilaporkan kepada pemegang saham (Lee, 1993: 82). Oleh karena itu, relevan jika diasumsikan bahwa auditor harus memiliki keahlian dan pengalaman yang memadai dan pantas untuk mencapai tujuan dari fungsi audit. Jika karakteristik personal ini kurang atau tidak memadai, maka bisa diduga bahwa auditor akan sukar mencapai tujuan auditnya.

Hal ini sejalan dengan penelitian Andy (2010) yang menyatakan bahwa kompetensi berpengaruh terhadap kualitas audit. Penelitian lain yang relevan dengan hasil penelitian ini adalah penelitian yang 
dilakukan oleh Muh. Taufiq Efendy (2010) dan Apriliyani et. Al. (2013) yang menyatakan bahwa komptensi memiliki pengaruh yang signifikan terhadap kualitas audit aparat inspektorat. Jawaban responden terhadap variabel kompetensi auditor, juga menunjukkan bahwa rata-rata auditor telah memiliki kompetensi yang memadai. Hal ini diperlihatkan pada jawaban responden yang banyak menjawab setuju pada indikator-indikator yang dikemukakan pada kuesioner seperti pengalaman dan pendidikan yang pernah diikuti oleh auditor. Hal ini juga turut mempengaruhi kualitas audit yang dihasilkan oleh auditor. Pengaruh Due Professional Care terhadap Kualitas Audit.

Hasil penelitian menunjukkan bahwa Due Professional Care berpengaruh signifikan terhadap Kualitas audit. Pengujian statistik uji t yang dilakukan menunjukkan bahwa nilai signifikansi variabel due professional care sebesar 0,044 dimana lebih kecil dari tingkat signifikan 0,05 sehingga hipotesis yang dibuat diterima. Hasil penelitian ini mendukung standar pada SPAP 2001 yang menyatakan bahwa dengan adanya kecermatan dan keseksamaan yang dilakukan oleh seorang auditor, maka diharapkan kualitas audit yang dihasilkan akan semakin baik, setiap pendapat yang diberikan oleh auditor dan penyajiannya diharapkan telah mengikuti pedoman yang tercantum dalam standar auditing. Penelitian tentang pengaruh due professional care terhadap kualitas audit telah dilakukan oleh beberapa peneliti, diantaranya Icuk (2010) menyebutkan due profesional care berpengaruh positif terhadap kualitas audit. Penelitian Louwers dkk. (2008) yang menyimpulkan bahwa kegagalan audit dalam kasus fraud transaksi pihak-pihak terkait disebabkan karena kurangnya sikap skeptis dan due professional care auditor daripada kekurangan dalam standar auditing.

Hasil penelitian menunjukkan bahwa responden telah memiliki due professional care yang cukup baik. Hal ini dikarenakan responden banyak menjawab setuju terhadap indikator- indikator yang dikemukakan pada kuesioner seperti mengumpulkan bukti yang cukup pada saat melaksanakan audit dan melakukan pengujian terhadap bukti yang ada. Hal ini turut mempengaruhi kualitas audit yang dihasilkan.

\section{SIMPULAN}

Kompetensi Auditor (X1), dan Due Professional care (X2) secara simultan berpengaruh positif secara signifikan terhadap Kualitas Audit (Y) APIP pada Inspektorat Provinsi Riau. Ini berarti bahwa jika variabel bebas yaitu variabel X1, X2 bertambah secara bersama-sama, maka akan memberikan pengaruh yang signifikan terhadap Kualitas Audit dan begitu juga jika terjadi hal sebaliknya. Kompetensi Auditor secara parsial memiliki pengaruh yang signifikan terhadap kualitas audit. Hal ini berarti bahwa jika variabel Kompetensi Auditor bertambah baik maka hal ini akan berpengaruh signifikan terhadap meningkatnya Kualitas Audit APIP pada Inspektorat Provinsi Riau dan begitupula sebaliknya. Due Professional care secara parsial memiliki pengaruh yang signifikan terhadap kualitas audit. Hal ini berarti bahwa jika variabel due professional care bertambah baik maka hal ini akan berpengaruh signifikan terhadap meningkatnya Kualitas Audit APIP pada Inspektorat Provinsi Riau dan begitupula sebaliknya.

\section{DAFTAR RUJUKAN}

Alim, M. Nizarul 2007, Pengaruh Kompetensi dan Independensi terhadap Kualitas Auditor dengan Etika auditor sebagai variabel moderasi, Simposium Nasional Akuntansi X.

Andy Perdana Handoyo, 2010, Pengaruh Kompetensi dan Indepedensi terhadap kualitas Audit, Jurnal Akuntansi, Universitas Airlangga.

Apriliyani, I. Berty, Anugerah Rita, dan Nurmayanti Poppy, 2013, Faktor- 
faktor yang Mempengaruhi Kualitas Audit APIP pada Inspektorat Provinsi Riau, Pekbis Jurnal Vol. 5 No. 3 hal,145-158, Universitas Riau.
Guy, Dan.M, C. Wayne Alderman, Alan J. Winters. 2002. Auditing Jilid 1. 5th edition. Jakarta: Penerbit Erlangga

Arens, Alvin, A. dan James, K. Icuk Rangga Buwono, 2010, Faktor-faktor Loebbecke. 2006. Auditing and Assurance Services An Integrated Approach. International Edition, Eleventh Edition. NewJersey: Prentice- Hill Inc.

Azwar, Saifuddin. 2003. Reliabilitas dan Validitas . Pustaka Pelajar : Yogyakarta.

BPKP. 1998. Modul Diklat Peningkatan Kemampuan Auditor . Unit Pengelola Pendidikan dan Latihan Pengawasan BPKP DI Jakarta.

Carcello, JV., Hermenson,RH. danNT. McGrath (1992). Audit Quality Attributes: The Perceptions of Audit Partners, Prepares, and Financial Statement Users, Auditing: A Journal of Practise \&Theory.

Davidson, R.A., dan D. Neu. 1993. "A Note on The Association between Audit Firm Size and Audit Quality". Contemporary Accounting Research. 9 (Spring). pp. 479-488.

DeAngelo, L.E. 1981. "Auditor Size and Audit Quality". Journal of Accounting and Economics. December. pp. 183-199.

Erlina, Sri Mulyani, 2007. Metodologi Penelitian Bisnis : Untuk Akuntansi dan Manajemen, Cetakan Pertama USU Press, Medan.

Ghozali, I. 2006a. Aplikasi Analisis Multivariate dengan Program SPSS. Badan Penerbit Universitas Diponegoro. Semarang. dalam diri auditor dan kualitas audit pada KAP "big four" di Indonesia. Jurnal Akuntansi. Universitas Sudirman, Surabaya

Jogiyanto.(2004). Metodologi Penelitian Bisnis : Salah Kaprah dan Pengalaman-Pengalaman. Universitas Gadjah Mada,Yogyakarta.

Kaplan, R. M., Sacuzzo, D. P. (1993). Psycological Testing Principles, Aplication, and Issue. California: Broks/Cole Publishing Company.

Lee, C.J., C. Liu, dan T. Wang. 1999. "The 150-hour Rule". Journal ofAccounting and Economics. 27 (2). pp. $203-228$.

Lee, T.A. 1993. Corporate Audit Theory. London: Chapman \& Hall.

Lowensohn, S., L. E. Johnson., R. J. Elder dan S. P. Davies. 2007. "Auditor Specialization, Perceived Audit Quality, and Audit Fee in the Local Government Audit Market." Journal Of Accounting and Public Policy, 26 705-732.

Louwers, Timothy J., Elaine Henry, Brad J. Reed, and Elizabeth A. Gordon. 2008. Deficiencies in Auditing Related-Party Transactions: Insights from AAERs. Current Issues in Auditing. Vol. 2. Issue 2. Pages A10-A16.

Mautz, R. K., dan Sharaf, H. A. (1961). The Philosophy of Auditing. Florida:American Accounting Association. 
Mulyadi. 2002. Auditing. Edisi 6. Badan Taufiq Penerbit Salemba Empat, Jakarta. Kompetensi, Indepedensi, dan MotivasiTerhadap Kualitas Audit

Murtanto. 2005. "Sistem Pengendalian Internal untuk Bisnis". Hecca Publishing. Jakarta. Indonesia.

Nugroho Agung, 2005. Strategi Jitu memilih Metode statistic Penelitian dengan SPSS, Andi Jogyakarta

Nur Indriantoro dan Bambang Supomo. 1999. Metodologi Penelitian Bisnis. BPFE: Yogyakarta.

Riduwan Akdon,. (2008). Rumus dan Data dalam Analisis Statistika. Bandung: Alfabeta

Samelson, D., S. Lowensohn. dan L. E. Johnson. 2006. "The Determinants ofPerceived Audit Quality and Auditee Satisfaction in Local Government."Journal of Public Budgeting, Accounting \& Financial Management", 18 (2):139-166.

Sugiyono. 2001. Metode Penelitian Bisnis. Alfabeta.Bandung. Aparat Inspektorat dalam Pengawasan Keuangan Daerah (Studi Empiris pada Pemerintah Kota Gorontalo) Tesis Universitas Diponegoro

Titman, S., dan B. Trueman. 1986. "Information Quality and The Valuation of New Issues". Journal of Accounting and Economics. 8 (June). pp. 159-172.

Umar Husein. (2008). Metode Penelitian untuk Skripsi dan Tesis Bisnis. Jakarta : PT RajaGrafindo Persada.

Watkins, A.L. W. Hillison, dan S.E. Morecroft. 2004. "Audit Quality: A Synthesis of Theory and Empirical Evidence". Journal of AccountingLiterature. 23. pp. 153193. 